\title{
Investigation of Seawater Intrusion into Coastal Groundwater Aquifers of Escravos, Western Niger Delta, Nigeria
}

\section{*11OHWOGHERE-ASUMA, OGHENERO; ${ }^{2}$ ESSI, OGHENEVOVWERO EMMANUEL}

\author{
${ }^{I}$ Department of Geology, Delta State University, Abraka \\ ${ }^{2}$ Department of General Studies, School of Marine Technology, Burutu, Delta State \\ Email: ohwonero@yahoo.com
}

\begin{abstract}
In coastal regimes groundwater aquifers are often vulnerable to saltwater intrusion. Saltwater intrusion is often precipitated by natural hydrodynamic processes and overpumping of groundwater resource. Saltwater intrusion is presumed to have significant effect on quality of groundwater and accountable for lack of access to freshwater in the areas under study. The objective of this study is to use resistivity data obtained from vertical electrical sounding to ascertain the salinity of shallow aquifers, determine depth and thickness of freshwater aquifers. The Schlumberger array configuration was employed in acquisition of data. The maximum and minimum spacing between electrodes $(\mathrm{AB} / 2)$ ranged from $2 \mathrm{~m}$ to $250 \mathrm{~m}$. Resistivity values ranged from $0.24 \Omega \mathrm{m}$ to $427 \Omega \mathrm{m}$, Values which ranged from $0.2 \Omega \mathrm{m}$ to $4 \Omega \mathrm{m}$ was construed to be aquifer saturated with saltwater, brackish water was inferred from resistivity values which vary between $7 \Omega \mathrm{m}$ and $11 \Omega \mathrm{m}$, and clay was assigned to resistivity values that ranged from $17 \Omega \mathrm{m}$ to $29 \Omega \mathrm{m}$. Effect of tide contributes to salinity of shallow aquifer around the seashore area. Aquifers saturated with saltwater are found at the depths of $10.5 \mathrm{~m}$, brackish water at $4 \mathrm{~m}$ to $9 \mathrm{~m}$, while freshwater can be located from the depth of $19-46 \mathrm{~m}$. The study is able to reveal that groundwater quality has been compromised by intrusion of saltwater. We conclude that there is potential of saltwater intrusion into the freshwater lenses, which may be enhanced in the future by over- development of groundwater. (C JASEM

https://dx.doi.org/10.4314/jasem.v21i2.18
\end{abstract}

Key words: Escravos, Vertical electrical sounding, Saltwater Intrusion, freshwater lenses, Aquifer, groundwater

Globally groundwater contributes a greater percentage of water usage in domestic, irrigation of agricultural farms and industrial purposes. Though groundwater is not the only form of water available to man, its preference to surface water is influenced by the degree of its protection from contaminants and its availability in arid and semi-arid areas of the world. The over reliance on groundwater compared to other sources of water has subjected groundwater to quality degradation and lack of its availability. Boreholes are often abandoned, when the aquifers they are tapping from are contaminated with saltwater. Consequently, groundwater from such aquifers are no longer portable, the effect of which is attendant reduction in the quantity of groundwater available to users.

Most faced with these myriad problems are those communities inhabiting coastal regions of the world. Coastal regions are characterized by the problem of saltwater intrusion, which reduces the quality of groundwater and renders it worthless. At the region where groundwater flow from inland areas and discharges into the ocean and estuary, there is saltwater interface which is usually initiated by recirculation of saltwater. This region is known as the saltwater-freshwater interface. It is usually at equilibrium, and can only be altered by overpumping as well as natural hydrodynamic processes. When the saltwater-freshwater interface moves inland as result of pumping, it is known as saltwater intrusion. Intrusion of saltwater into freshwater aquifer has attendant effect on decreasing the higher resistivity common to uncontaminated groundwater. At the saltwater-freshwater interface there is gradual decrease with resistivity with depth, indicating movement from freshwater to saltwater zones respectively. The existence of such resistivity contrast at the interface has led to the advantage of using electrical resistivity survey in the delineation of saltwater from freshwater aquifers in coastal areas.

The problem of intrusion and associated groundwater quality deterioration can be surmounted by early prevention of its occurrence, which is paramount for coastal aquifers management and sustainability of fresh groundwater. Using electrical resistivity monitoring the movement of the freshwater interface 
is one sure way of early detection. The reason is that remediation is quite expensive and time consuming for re-freshening of intruded aquifers (Domenico and Schwartz (1998). Electrical resistivity survey and electromagnetic are important techniques for monitoring the movement of saltwater- freshwater interface.

Several studies around the globe involving the use of VES and 2D electrical resistivity imaging in the study of saltwater intrusion are available in the literature. Saltwater zones were revealed from VES at coastal area of Deghele in Warri South West (Atakpo, 2013). Saltwater bearing aquifer was found occurring at depth of 30-90m area of Bonny Island in the eastern Niger Delta region from VES and geochemistry (Amadi et al. 2012). Saltwater intrusion caused by ancient seawater-flooding of beach was detected by 2D ERI in coastal aquifer of Selangor, Malaysia (Baharuddin et al. 2009). Other electrical resistivity studies includes; Dead Sea (Batayneh, 2006); Burutu (Ohwoghere-Asuma et al. 2012); Warri (Ohwoghere-Asuma et al. 2014); India (Ravindran and Ramanujam, 2012).

The study area lacks access to groundwater as indicated by absence of hand-dug wells availability, despite the closeness of groundwater table to the ground surface. Since there are no shallow dug wells in the area, the only source of water for the inhabitants of the study area is mainly from one of the oil companies operating in the area. The objective of this paper is to use resistivity data obtained from vertical electrical sounding to ascertain the salinity of shallow groundwater aquifer, determine depth and thickness of freshwater aquifer.

\section{MATERIALS AND METHODS}

Description of Location of Study: Escravos area comprising Ajadaibo and Ogidigben is located on Latitude 5.5833N and Longitude 5.1667 E (Fig. 1). It falls within the abandoned beach ridge of the Niger Delta. It is a riverine rural community in Delta State, Nigeria, which became popular nationally and internationally as result of activities of oil and gas exploration and exploitation activities. It consists typically of mangrove and freshwater swamps, with seashore areas of Ajadaibo having more mangrove vegetation than Ogidigben town with dominant freshwater swamps vegetation, such as palm tree and shrubs. However, there mangrove swamps increases with distance towards the ocean. These mangrove and freshwater swamps vegetation is typical of the Niger delta. They are typically found cross all the coastal regions of the Niger Delta.

The area is demarcated from the sea by beaches and barrier islands. It is bounded in the south by the margin of the Atlantic basin and the Escravos River in the south. The occupation of the people is majorly fishing and periwinkles picking from the sea. The area hosts the Escravos terminal for export of Nigeria crude oil, Escravos-gas-to-Liquid plant and in future the Gas Revolution Industrial City Project and numerous oil wells

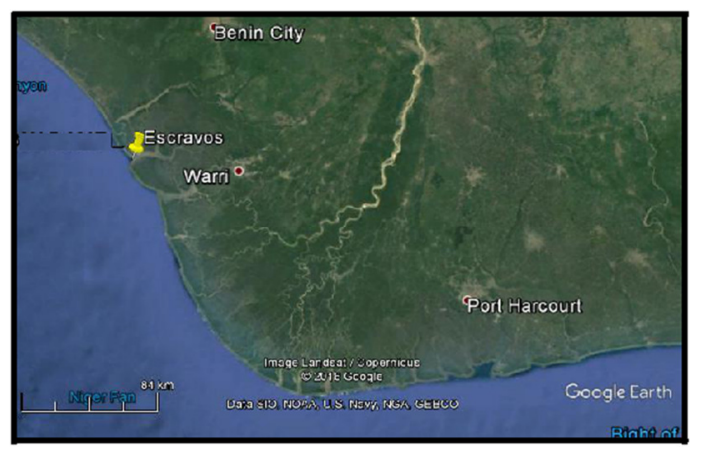

Fig. 1: Map of the Niger Delta showing the study area

Geological setting: Escravos falls within the geomorphologic unit of abandoned beach ridges and hydrogeologic units of the Niger Delta hydrogeological basin (Akpokodje, 2011). The subsurface geologic composes of sediments deposited by the fluvial and tidal influences of the sea. Sediments routing have been through the Benin River, River Escravos, Forcados River and the Niger
River and their distributaries. Geologically, the sediments belong to the Quaternary deposits of the Benin Group, which mantled the other stratigraphic units of the Agbada and Akata of the Niger Delta Basin (Rejier 2011). The prevailing hydrodynamic of oceanic stressing, wave and loading of sediments assisted in the lithification of sediments and reworking of deposited sediments. In a river routing 
systems, the depositional energy tends to decrease as the river approaches the mouth of the delta and the shallow continental shelf. At the upper and lower shore faces, tide and waves energy are strong and are dominant for the reworking and reshaping of the coastline.

Typical sediments include sands, silts, clays and mudflats and the sands with scanty shells of marine organisms. Recent sedimentary structure include cross beddings and burrowing. Burrowing is by living (Mollusca) marine craps and oyster (periwinkles). Detail works about the geology Niger delta exist in literature and can be found in (Ohwoghere-Asuma et al. 2012; Rejier, 2011; Magbagbeoloa and Willis, 2007; Owoyemi and Willis, 2006, Ejedawe, 1981).

Hydrogeology: The area is characterized by aquifers that are unconfined and confined. The presence of these aquifers are affected by depositional environment, the sands are the aquifers, while the clays are the aquicludes and confining. Intercalation of sand with clays is also common. The subsurface geologic formation consists of alternation of clays and sand compared to inland areas of the delta. Quality of groundwater to a large extent is controlled by dissolved iron rich sand aquifer materials and saltwater intrusion. A groundwater table range from near the ground surface to $0.31 \mathrm{~m}$ and fluctuates with respect to the two dominant seasons that characterized the area. Flow of groundwater is toward the sea and estuary. Aquifer hydraulic productivity is affected by intercalation of clays and silts as well as pinches out.

The catchment is drained by the Escravos River, creeks, tidal inlets and marshes, swamps. In this area comprising the study area, the Ecrsavos River is mostly saline and brackish. According to the world weather online assessed on 1/03/2016 reported on their website that the monthly mean of rainfall for period of 2000-2012 ranged from 3mm to $216 \mathrm{~mm}$ for the Escravos areas. Run off is relatively low due to flat topography nature of the area which promotes high infiltration rate. The swamps, marshes and creeks are sort of depression which receive direct precipitation.

Field acquisition and Processing: In order to probe the subsurface geologic formation and the attendant effect of delineating freshwater aquifers intruded by saltwater, a 4light Power 10W Earth Resistivity Meter was used for Sounding. The schlumberger array configuration was employed for acquisition of data (Fig. 2). The depth of subsurface that may be depicted by the VES is dependent on the horizontal electrode separation. The maximum and minimum spacing of $A B / 2$ used ranged from $2 \mathrm{~m}$ to $250 \mathrm{~m}$, the swampy nature of the study area limited the extension of the spacing. The vertical depth penetrated is usually two-third of longest electrode spacing on the ground (Vingoe, 1972).

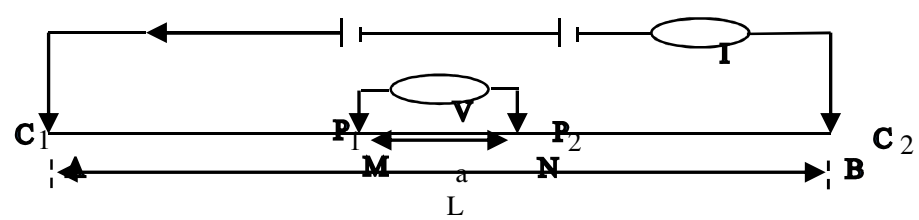

Fig. 2: Schlumberger array Configuration

The procedure involves injecting current via two current electrodes ( $\mathrm{C} 1$ and $\mathrm{C} 2$ ) into the subsurface geology. The response of the subsurface earth materials to introduced current is measured by two potential electrodes (P1 and P2). The equipment displayed the result of resistivity of the geologic material in the subsurface in apparent resistivity format. The equation of Keller and Frischknecht (1979), which relate apparent resistivity to current, potential and resistance is shown in equation (1).

This result of equation 1 is not actually true representative of the resistivity of the subsurface, but

$$
\rho a=\pi r\left[\frac{a^{2}}{b}-\frac{b}{4}\right\rfloor \text {-------------- equation }
$$

an apparent resistivity, which must be processed further. In order to convert apparent resistivity to the rue resistivity of the subsurface, the data were plotted on Logarithm - Logarithm graphic paper and were subsequently matched with master curve and auxiliary chart (Orellana and Mooney, 1966). Thereafter, geologic layers and thickness interpreted were inputted into an inversion software called winResist (Vander, 2004). The reason for using this procedure is to minimize errors often common to interpretation using master curve and axillary chart (Barker, 1989) alone.

OHWOGHERE-ASUMA, OGHENERO; ESSI, OGHENEVOVWERO EMMANUEL 
Where;

$$
\begin{aligned}
& \rho a=\text { apparent resistivity } \\
& \mathrm{r}=\text { subsurface earth material resistivity } \\
& \mathrm{a}=\text { current electrode } \\
& \mathrm{b}=\text { potential electrode }
\end{aligned}
$$

\section{RESULTS AND DISCUSSION}

The summarized results of the interpreted computer iterated field data are shown in Table 1 and geologic section across the area is also shown in Fig. 5. The geologic of the subsurface is divided into 6 layers. The topmost layer possesses resistivity of $11 \Omega \mathrm{m}$ and thickness of $0.333 \mathrm{~m}$. VES 1 is relatively near the seashore area located near 911 night club at Ajadaibo (Fig. 3). Immediately underlying this are two layers, with resistivity of $4.82 \Omega \mathrm{m}$ and $9.29 \Omega \mathrm{m}$ occurring at depths of $2.9 \Omega \mathrm{m}$ and $4.9 \Omega \mathrm{m}$ and with thickness of $1.7 \mathrm{~m}$ each. The effect of tidal forcing may be responsible for the inundation of the surface around the area with saltwater, especially at high tide (Robinson and Barry, 2007). The mixing of saltwater with precipitation may be the reason for the low resistivity of the topmost layer. These layers are probably influenced by the infiltration of saltwater from effect of saltwater inundation. Below them is distinctively very low resistivity of $0.401 \Omega \mathrm{m}$ layer at $10.5 \mathrm{~m}$ depth and with thickness of $5.78 \mathrm{~m}$.

The low resistivity which characterized this layer possibly suggests intrusion of saltwater as result of interaction between the aquifer and the Ocean or the point where there is recirculation of freshwater from the ocean. The intrusion is probably caused by natural hydrodynamic processes associated with aquifers that are hydraulically linked to the Ocean. The possibility of this assertion emanates from the fact that there is no existing borehole, where groundwater is being pumped in this areas. Therefore over-exploitation of groundwater resources is not the likely reason there is intrusion in this area. At the depth of $25.27 \mathrm{~m}$ is freshwater bearing sand aquifer

\begin{tabular}{|c|c|c|c|c|c|}
\hline Location & VES & Resistivity $(\Omega m)$ & m) & $\operatorname{Depth}(m)$ & Geology inferences \\
\hline \multirow{16}{*}{ Ajadaibo } & 1 & 11.21 & 0.38 & 0.38 & Top moist soil \\
\hline & & 20.01 & 0.77 & 1.16 & Sandy section \\
\hline & & 4.82 & 1.76 & 2.92 & (saturated with brackish) \\
\hline & & 9.29 & 1.79 & 4.72 & \\
\hline & & 0.40 & 5.78 & 10.50 & Sand ( saturated with Saltwater) \\
\hline & & 324.87 & 14.77 & 25.27 & Sand (saturated with freshwater) \\
\hline & & 65.79 & 21.24 & 46.52 & Clay \\
\hline & & 1.49 & $?$ & $?$ & Sand with saltwater \\
\hline & 2 & 42.74 & 0.51 & 0.51 & Moist top soil \\
\hline & & 25.94 & 0.69 & 1.21 & Sandy \\
\hline & & 22.41 & 1.42 & 2.60 & (Saturated with Brackish water) \\
\hline & & 10.30 & 3.99 & 6.61 & \\
\hline & & 59.74 & 4.20 & 10.81 & \\
\hline & & 427.71 & 15.03 & 25.84 & Sand/freshwater \\
\hline & & 27.49 & 37.59 & 63.42 & (Sand with brackish water) \\
\hline & & 5.63 & $?$ & $?$ & \\
\hline \multirow{16}{*}{ Ogidigben } & 3 & 50.80 & 0.59 & 0.59 & Moist top soil \\
\hline & & 25.55 & 0.97 & 1.56 & Clay \\
\hline & & 10.28 & 3.08 & 4.65 & \\
\hline & & 16.91 & 2.87 & 7.52 & \\
\hline & & 1.10 & 4.30 & 11.82 & \\
\hline & & 2.99 & 4.94 & 16.76 & \\
\hline & & 137.67 & 19.94 & 36.38 & Sand / freshwater / \\
\hline & & 0.40 & ? & ? & Sand water \\
\hline & 4 & & & & \\
\hline & & 61.80 & 0.39 & 0.39 & Top moist soil \\
\hline & & 29.56 & 1.29 & 1.69 & \\
\hline & & 7.06 & 1.25 & 2.94 & Clay \\
\hline & & 17.16 & 1.82 & 4.76 & \\
\hline & & 1.30 & 4.00 & 8.77 & \\
\hline & & 130.87 & 10.42 & 19.89 & Sand / freshwater \\
\hline & & 43.624 & 9.76 & 28.94 & Sand / Brackish water/ saltwater \\
\hline
\end{tabular}
with resistivity of $325.87 \Omega \mathrm{m}$

Table 1: Summary of resistivity interpretation and with thickness of $14.77 \mathrm{~m}$. Immediately below this, is another layer with resistivity of $65.791 \Omega \mathrm{m}$ occurring 
at $46.56 \mathrm{~m}$ and with thickness of $16.244 \mathrm{~m}$. The subsurface geologic information interpreted for this layer is clay. The last layer with resistivity of $1.49 \Omega \mathrm{m}$ whose thickness and depth of occurrence could not be ascertained probably indicates saltwater intrusion. Since it is underlying a confining layer, it possibly represents marine water that was trapped in sediment during the last Holocene marine transgression. Similar result has been reported by (Oyedele and Momoh, 2009; Atakpo, 2013) for the coastal area in Victoria Island of Lagos and Deghele in Warri South West of Delta state.

4 Geologic layers were interpreted from VES 2, its resistivity values ranged from $5.625 \Omega \mathrm{m}$ to $427.72 \Omega \mathrm{m}$ (Fig, 3). The topmost layer has resistivity of $42.70 \Omega \mathrm{m}$ with thickness of $0.51 \mathrm{~m}$ and occurred at the depth of $0.51 \mathrm{~m}$. The modest resistivity values of $42.70 \Omega \mathrm{m}$ inferred for the top layer suggests no influence of tide unlike the first. Underneath the layer is a geologic section with resistivity values that ranged from $25.94 \Omega \mathrm{m}$ to $59.74 \Omega \mathrm{m}$. There is a distinctive decrease in resistivity and a sudden increase from $10.30 \Omega \mathrm{m}$ to $59.74 \Omega \mathrm{m}$ in this geologic section. This is an indicative of increase in the salinity of groundwater with depth. On comparing the section with borehole information available, these two layers were interpreted as sand saturated with brackish water. These depths appeared to be the continuation of those of section one. As evidenced by the resistivity values, the salinity increases vertically in this layer and decreases laterally from that of section one. The observation is in agreement that saltwater bearing aquifer thickness reduces and freshwater increases as the distance from the coast towards the land increases. Underlying the two brackish water saturated layers, is a layer located at the depth of $25 \mathrm{~m}$ which possess resistivity of $427.72 \Omega \mathrm{m}$ and thickness of $15.03 \mathrm{~m}$. The subsurface geologic formation for this layer was interpreted as sand with freshwater bearing. It could also be considered as thin lens of freshwater aquifer. Below it is layer with resistivity of $27.49 \Omega \mathrm{m}$ situated at the depth of $63 \mathrm{~m}$ and with thickness of $37.7 \mathrm{~m}$. Brackish water bearing sand was inferred for this geologic section. Clearly, the underlying geologic layer supports the above assertion as shown by the decrease of resistivity from $27.49 \Omega \mathrm{m}-5.62 \Omega \mathrm{m}$. The probable condition responsible could be initiated by saltwater intrusion of the aquifer.

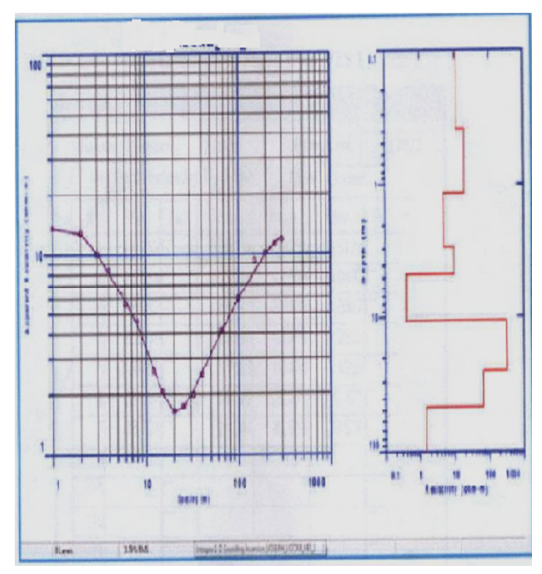

Fig, 3: Computer iterated curves for VES 1 and VES 2 acquired from Ajadiabo

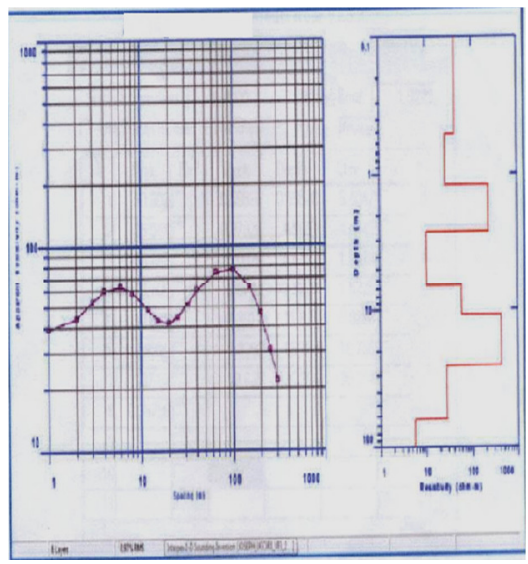

Fig, 3: Computer iterated curves for VES 1 and VES 2 acquired from Ajadiabo

The response of the subsurface geologic formation at VES 3 to introduced direct current (D.C) gave resistivity values which ranged from $0.40 \Omega \mathrm{m}$ to $137.67 \Omega \mathrm{m}$ (Fig. 4). The geologic layer with resistivity of $50.80 \Omega \mathrm{m}$ was interpreted as moisture soil and clay. The static water level is $0.3 \mathrm{~m}$ and considering the $0.595 \mathrm{~m}$ depth of this layer, it actually portrays a top soil saturated with water. Lower is a layer with resistivity of $25 \Omega \mathrm{m}$ and inferred clay material content for it, which increase with depth as shown by the other geologic layer beneath.
The other layers interpreted as clay are characterized by $10.20 \Omega \mathrm{m}, 16.90 \Omega \mathrm{m}, 1.097 \Omega \mathrm{m}$ and $2.99 \Omega$ mand thicknesses of $3.08 \mathrm{~m}, 2.87 \mathrm{~m}, 4.3 \mathrm{~m}$ and $4.93 \mathrm{~m}$ respectively. A cursory assessment of the displayed resistivity values with depth shown that all the layers are acting as a confining layer at the depth of $16.756 \mathrm{~m}$ for a freshwater bearing aquifer. This layer has resistivity of $137.87 \Omega \mathrm{m}$ and with thickness of freshwater of $19.62 \mathrm{~m}$. The $19.62 \mathrm{~m}$ thick freshwater lens is overlying a resistivity of $0.40 \Omega \mathrm{m}$, it thickness and depth at which it occurs could not be deduced. However considering the low resistivity values of this 
layer, saltwater is suggested. The interface between saltwater is therefore situated at the $36.384 \mathrm{~m}$. The position of the saltwater and freshwater zones deduced from the interpretation emphasizes the potential of up-coning of saltwater should the aquifer be subjected to over-abstraction of groundwater in the future.
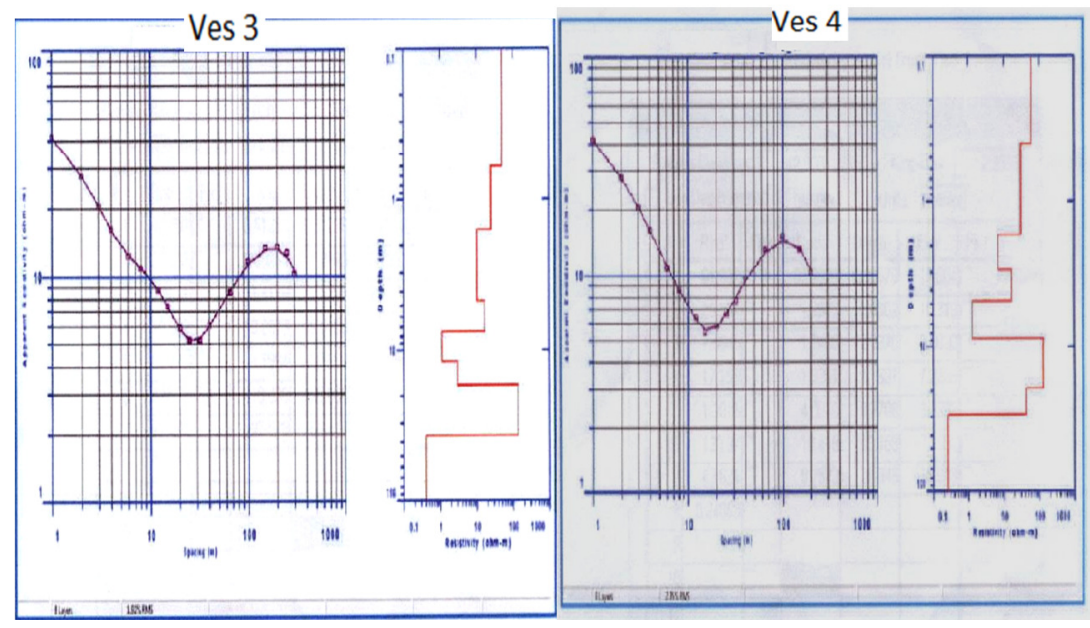

Fig. 4: Computer iterated curves for VES 3 and VES 4 acquired from Ogidigben

The electrical properties of the subsurface geologic formation for VES 4 are reflected in resistivity values which ranged from $0.26 \Omega \mathrm{m}$ to $130.87 \Omega \mathrm{m}$ (Fig. 4). The resistivity value of $61.80 \Omega \mathrm{m}$ is recognized as soil / clay and occurs at depths of $0.39 \mathrm{~m}$ and saturated with water by the position of the water table in the study area. Underlying the top layer is geologic sections consisting of variable resistivity of $29.56 \Omega \mathrm{m}, 7.06 \Omega \mathrm{m}, 17.159 \Omega \mathrm{m} 1.3015 \Omega \mathrm{m}$, which terminate at depth of $8.77 \mathrm{~m}$ as confining freshwater lens. The subsurface geologic formation sand bearing freshwater has resistivity of $130.87 \Omega \mathrm{m}$, thickness of $10.418 \mathrm{~m}$ and occurs at $19.189 \mathrm{~m}$ depth. Below it, is a sand bearing geologic formation characterized by resistivity of $43.64 \Omega \mathrm{m}$, thickness of $9.757 \mathrm{~m}$ and occurring at $28.96 \mathrm{~m}$. This low resistivity relatively different from that of saltwater may be an indication of saltwater intrusion and it is interpreted as brackish water. The very low resistivity of $0.248 \Omega \mathrm{m}$ of the underlying geologic formation is interpreted as saltwater. Again the interface of saltwater and freshwater in this section is $19.189 \mathrm{~m}$

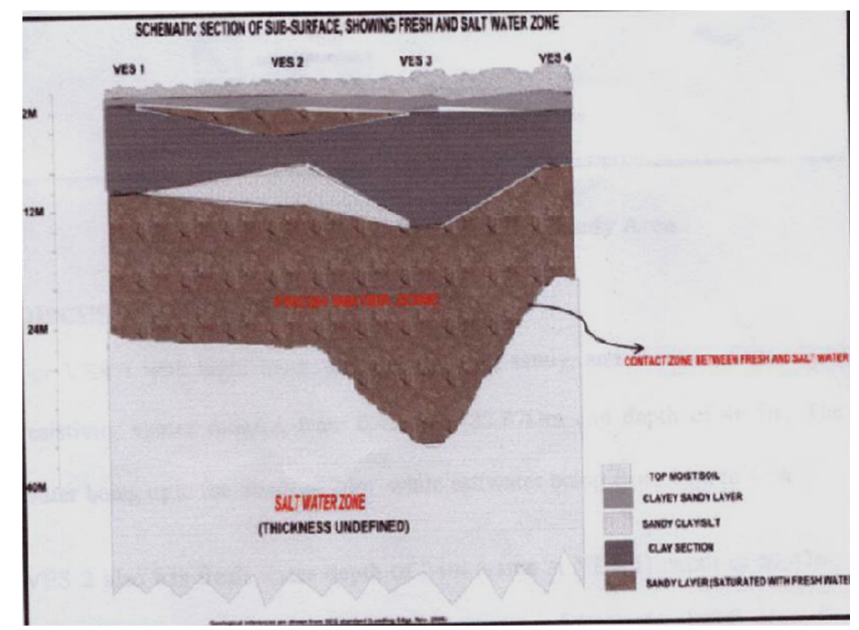

Fig. 5: Geologic section showing saltwater- freshwater interface 
Conclusions: This investigation revealed that groundwater quality of the study area has been compromised due to the presence of saltwater. The study also demonstrated that the saltwater/ freshwater interface is close to the sea and tends to decreases as the distance from the coast increases towards the inland areas. The freshwater aquifers can only be assessed through the drilling of boreholes as aquifers at shallow depths are contaminated by saltwater intrusion, hence the absence of hand-dug wells. Though intrusion is controlled by natural geologic processes, there is a potential of saltwater intrusion into groundwater aquifer from the sea and up-coning of trapped saltwater into aquifers is extremely possible in the future as freshwater aquifers are developed to meet population increases. Intrusion delineated is probably not caused by over- abstraction of groundwater but by natural hydrodynamic processes, which is different from coastal areas of the world characterized by high demand for groundwater adduced to increase in population and urbanization.

\section{REFERENCES}

Amadi, A.N, Nwankwoala, H.O., Olasehinde, P.O, Okoye, N.O., Okunlola, I.A., Alkali, Y.B (2012). Investigation of Aquifer Quality in Bonny Island, Eastern Niger Delta using Geophysical and Geochemical Techniques". Journal of Emerging Trends in Engineering and Applied Sciences (JETEAS). 3(1):183 - 187.

Akpokodje, E.G. (2011). Aquifer mapping and Characterization of Bayelsa State, An unpublished Report, Submitted to the Directorate of Environment, Pollution and Control, Niger Delta Development Commission. Pp. 19-34

Atakpo, E.A (2013). Geoelectric Investigation of Deghele Community in Warri South West L.G.A. Delta state, Nigeria, IOSR Journal of Applied Physics.3(1): 46-52

Baharuddin,M.F.T, Hashim, R., Taib, S (2009) Electrical Resistivity Imaging at the study at the coastal aquifer area of Segai, Besar, Selengor, Malaysia. Journal of Applied Science 9(16) 2897-2906,

Barker, R.D (1989). Depth of Investigation of Collinear Symmetrical Four-Electrode Arrays. Geophysics, 5:1031-1037.

Batayneh, A.T (2006). Use of Electrical Resistivity Methods for Detecting Subsurface Fresh and Saline Water and Delineating their Interfacial
Configuration: A Case Study of the Eastern Dead Sea Coastal Aquifers. Jordan.Hydrogeol. J. 1277-1283

Domenico, P.A; Schwartz, F.W (eds.) 1998: Physical and Chemical Hydrogeology (2nd edition). John Wiley and Sons, Inc. New York, U.S.A.

Ejedawe, J.E (1981). Patterns of Incidence of Oil Reserves in Niger Delta Basin. A. A. P. G. Bulletin 65: 1574-1585.

Keller, G.V; Frischknecht, F.C (1979). Electrical Methods in Geophysical Prospecting. Pergamon Press, New York. Pp. 91-135.

Magbagbeoloa, O; Willis, B.J (2007). Sequence Stratigraphy and Syndepositional Deformation of the Agbada Formation, Robertkiri Field, Niger Delta, Nigeria. A.A. P. G. Bulletin. 91: 945-958.

Ohwoghere- Asuma, O; Akpoborie, I,.A; Akpokodje, E.G (2014). Investigation of Saltwater Intrusion in Warri - Effurun Shallow Groundwater Aquifer from 2D Electrical Resistivity Imaging and Hydraulic Gradient Data, New York Science Journal. 7(12): 20-28

Ohwoghere-Asuma, O., Aweto, K.E., Akpoborie, I.A. (2012). Investigation of Groundwater Quality and Evolution in an Estuary Environment: A Case Study of Burutu Island Western Niger Delta, Nigeria. J. of Environ. Hydrol. 22 (5): 1-14

Orellana, E: Mooney, H.M (1996). Master Tables and Curves for Vertical Electrical Sounding Over Layered Structures, Intersciencia, Madrid, 34pp.

Owoyemi, A.O; Willis, B.J (2006). Depositional Patterns Across Syndepositional Normal Faults, Niger delta, Nigeria. J of Sedimentary Research 76: 346-363.

Oyedele, K.F; Momoh, E.I (2009). Evaluation of Sea Water Intrusion in Freshwater Aquifers in a Lagoon Coast: A Case Study of the University of Lagos Lagoon, Akoka, Nigeria. Academia Arena. 1(2): 44-54

Ravindran, A.A; Ramanujam., E.I (2012). A Case study of Crystalline Limestone Intrusion and Fault Zone Identication Using 2D ERI Technique in Ramco Cements, Pandalgudi Mines, Tamilnadu. Intern. Research J. of 
Geology and Mining (IRJGM) (2276-6618) 2:11-15.

Reijers, T.J.A. (2011). Stratigraphy and Sedimentology of the Niger Delta.Geologos. 17 (3): 133-162 doi: 10.2478/v10118-011-0008-3

Robinson, C.E; Li, L; Barry, D.A (2007). Effect of Tidal Forcing on a Subterranean Estuary. $A d v$ Water Resour. 30: 851-65.
Vander Velpen, B.P.A. (2004). WinResist Version 1.0. M.Sc. Research Project ITC, Deft, Netherland.

Vingoe, P (1972). Electrical Resistivity Surveying. ABEM Geophysical Memorandum. 5172:1 -13 . 